\title{
Genetic and epigenetic changes in primary metastatic and nonmetastatic colorectal cancer
}

\author{
E Miranda', A Destro', A Malesci' ${ }^{2}$, E Balladore', P Bianchi', E Baryshnikova', G Franchi', E Morenghi', \\ L Laghi $^{1,4}$, L Gennari ${ }^{5}$ and M Roncalli*, I,6
}

'Molecular Genetics Laboratory, Istituto Clinico Humanitas, University of Milan, Via Manzoni 56, Rozzano, Milano 20089, Italy; ${ }^{2}$ Departement of Gastroenterology, Istituto Clinico Humanitas, University of Milan, Via Manzoni 56, Rozzano, Milano 20089, Italy; ${ }^{3}$ Clinical Trial Office, Istituto Clinico Humanitas, University of Milan, Via Manzoni 56, Rozzano, Milano 20089, Italy; ${ }^{4}$ Departement of Gastroenterology, Istituto Clinico Humanitas, University of Milan, Via Manzoni 56, Rozzano, Milano 20089, Italy; ${ }^{5}$ Departement of Surgery, Istituto Clinico Humanitas, University of Milan, Via Manzoni 56 , Rozzano, Milano 20089, Italy; ${ }^{6}$ Departement of Pathology, Istituto Clinico Humanitas, University of Milan, Via Manzoni 56, Rozzano, Milano 20089, Italy

\begin{abstract}
Colorectal cancer (CRC) develops as multistep process, which involves genetic and epigenetic alterations. K-Ras, p53 and B-Raf mutations and RASSFIA, E-Cadherin and pI6INK4A promoter methylation were investigated in 202 CRCs with and without lymph node and/or liver metastasis, to assess whether gene abnormalities are related to a metastogenic phenotype. K-Ras, B-Raf and p53 mutations were detected in 27, 3 and $32 \%$ of the cases, with K-Ras mutations significantly associated with metastatic tumour $(P=0.019)$. RASSFIA, E-Cadherin and p/6INK4A methylation was documented in 20, 44 and 33\% of the cases with p/6INK4A significantly associated with metastatic tumours $(P=0.001)$. Overall, out of 202 tumours, $34(17 \%)$ did not show any molecular change, 125 (62\%) had one or two and 43 (21\%) three or more. Primary but yet metastatic CRCs were prevalent in the latter group $(P=0.023)$ where the most frequent combination was one genetic (K-Ras in particular) and two epigenetic alterations. In conclusion, this analysis provided to detect some molecular differences between primary metastatic and nonmetastatic CRCs, with K-Ras and p I 6INK4A statistically altered in metastatic tumours; particular gene combinations, such as coincidental K-Ras mutation with two methylated genes are associated to a metastogenic phenotype.
\end{abstract}

British Journal of Cancer (2006) 95, I I0I-I I07. doi: I0.1038/sj.bjc.6603337 www.bjcancer.com

Published online 12 September 2006

(c) 2006 Cancer Research UK

Keywords: colorectal cancer; genetic and epigenetic alterations; metastogenic phenotype

Colorectal cancer (CRC) is one of the most common malignant neoplasm worldwide. The prognosis is significantly affected by the tumour stage that mainly rests on the ability to metastasise to lymph nodes and/or to the liver. Indeed, the 5-year-survival is over $90 \%$ for Duke's stage A, but only $5 \%$ for Duke's stage D (de la Chapelle, 2004). Sequential and additional genetic alterations affecting several proto-oncogenes and tumour suppressor genes have been recognised in the pathogenesis of CRC. Less known are the molecular events responsible for the progression and metastatisation of $\mathrm{CRC}$; it is reasonable that the molecular profile of primary but yet metastatic CRC may be helpful to understand the molecular basis of extracolic tumour spread and to define therapeutic strategies against 'metastogenic' genes. Previous studies targeted to ascertain the molecular progression of CRC investigated genetic abnormalities of proto-oncogenes ( $K$-Ras) and tumour suppressor genes ( $p 53$ and $A P C$ ) or, alternatively, molecular epigenetic changes (E-Cadherin, p16INK4A, DAPK,

*Correspondence: Professor M Roncalli, Departement of Pathology, Istituto Clinico Humanitas, University of Milan, Via Manzoni 56, Rozzano, Milano 20089, Italy; E-mail: massimo.roncall@unimi.it

Received 12 April 2006; revised 25 July 2006; accepted 31 July 2006; published online 12 September 2006
RASSF1A and APC) (Smith et al, 2002; Lee et al, 2004). The present study was aimed to investigate both genetic and epigenetic changes occurring in CRC by comparing the molecular profiles of primary metastatic and nonmetastatic tumours. We selected for study the mutational status of $K$-Ras, $B$-Raf and $p 53$ and the epigenetic status of RASSF1A, E-Cadherin and p16INK4A.

Abnormalities of $K-R a s$ are key events in colorectal carcinogenesis and mutations of the gene arise early during the colonic transformation in 20-50\% of the tumours (Bazan et al, 2002). $K$-Ras has been also implicated in the process of tumour invasion and metastasis (Giehl, 2005). Mutations that prevalently occur at codon 12, prevent efficient GTP-hydrolysis and thus render the protein in an activated state. As a result, multiple Ras effector pathways, which control fundamental biological processes such as proliferation, apoptosis and cell motility become constitutively activated and/or deregulated (Pollock et al, 2005). The best characterised Ras effectors are the Raf serine/threonine kinases (A-Raf, B-Raf and Raf-1) that upregulate the MAP kinase cascade (Kolch, 2000). Davies et al (2002) recently reported that $B$-Raf mutations play a pivotal role in the oncogenesis of melanoma and colorectal carcinoma. The majority of analysed samples exhibited one specific $B$-Raf alteration that caused the exchange of valine to glutamate, a negatively charged amino acid, at position 599 (V599E) in the kinase domain of the protein. Interestingly, it has 
been shown that this alteration causes the growth of carcinoma cell lines independent from Ras activation.

The $p 53$ suppressor gene encodes a nuclear phosphoprotein that regulates cell cycle and apoptosis. Mutations in this gene constitute some of the most frequently occurring genetic changes at human malignancies and are thought to be late development in the adenoma-carcinoma sequence in CRC (Fearon and Vogelstein, 1990). Mutations in this gene increase the protein half-life and are often associated with protein overexpression in the nucleus (Remvikos et al, 1990). Mutations most commonly occur in the highly conserved region (exons 5-8), which encodes the DNAbinding domain (Zhang et al, 1997).

During the last decade, epigenetic changes have been reported in many cancers and they are now recognised to be at least as common as genetic changes. Hypermethylation of selected CpG sites within $\mathrm{CpG}$ islands in the promoter region of tumour suppressor genes is associated with loss of gene expression and is observed in both physiological conditions and neoplasia (Kim et al, 2005b). By inactivating various tumour suppressor genes, this epigenetic modification can affect many important cellular processes, such as cell proliferation, apoptosis, invasion and metastasis.

RASSF1 proteins are potential Ras effectors and the major isoform, RASSF1A, is an important human tumour suppressor protein acting at G1/S phase of cell-cycle progression (Dammann et al, 2003). This protein can induce cycle arrest by cyclin D1 inhibition. The RASSF1A locus at $3 \mathrm{p} 21.3$ is methylated at high frequency in a variety of solid tumours including CRC, where this gene has been analysed as an alternative marker to downregulate Ras pathway (Pizzi et al, 2005).

E-Cadherin belongs to a family of $\mathrm{Ca}^{2+}$-dependent adhesion molecules that mediate intercellular contacts critical to morphogenesis and the maintenance of tissue structure (Takeichi, 1995). Reduced expression of E-Cadherin owing to aberrant CpG island hypermethylation has been regarded as one of the main molecular events involved in the dysfunction of the cell-cell adhesion system (Darwanto et al, 2003), in invasion and metastasis (Garinis et al, 2002). Recently, it has been shown that loss of E-Cadherin expression in a transgenic mouse model is associated with the development of invasive colorectal carcinoma from well-differentiated adenomas (Wheeler et al, 2001).

p16INK4A gene is one of the most frequently inactivated tumour suppressor genes in human cancer (Kamb et al, 1994). The p16INK4A product, an inhibitor of cyclin-dependent kinases 4 and 6 , is capable of preventing $\mathrm{Rb}$ phosphorylation, thus blocking cells in the G1 phase of the cell cycle (Serrano et al, 1996). It is known that p16INK4A expression in colon cancer cells is repressed by methylation at the $\mathrm{CpG}$ island of promoter, but in vivo silencing of p16INK4A methylation has not been widely investigated (Kim et al, 2005a).

We designed a study aimed to compare genetic and epigenetic changes occurring in primary advanced nonmetastatic CRCs as opposed to primary advanced metastatic CRCs. The target was to establish in CRCs if and which genetic and epigenetic molecular abnormalities, among a number of selected genes, are associated to a metastogenic phenotype.

\section{MATERIALS AND METHODS}

\section{Patients}

This study includes 202 consecutive primary advanced metastatic and nonmetastatic CRCs surgically removed from 1997 to 2002. Table 1 reports the main clinico-pathological features of the series. We elected to study and to compare two homogeneous groups of CRC cases, namely those invading through muscolaris mucosa into subsierosa (or into nonperitonealised pericolic or perirectal tissues) with and without lymph nodes and/or liver metastases. In such a way, the only significant morphological and biological variable between the two groups was the presence of metastatic deposits. Accordingly, these two groups will be referred to throughout the paper as metastatic $(\mathrm{M}+)$ and nonmetastatic $(\mathrm{M}-)$ tumours.

\section{DNA extraction}

Samples were fixed in formalin and embedded in paraffin. Paraffin blocks were cut into several $2 \mu \mathrm{m}$ sections. One section from each tissue was stained with hematoxylin-eosin to distinguish neoplastic tissue from the nonmalignant counterpart. After manual dissection, DNA was extracted from the unstained section of the malignant tissue as described previously (Roncalli et al, 2002). Briefly, tissue sections were deparaffinised using $100 \%$ xylene (Sigma, Saint Louis, MO, USA) followed by $100 \%$ ethanol. The pellet was then resuspended in a buffer containing proteinase $\mathrm{K}$ (Finnzyme, Espoo, Finland), and DNA was extracted with phenolchloroform (Sigma, Saint Louis, MO, USA) followed by ethanol precipitation. Finally, precipitated DNA was resuspended in $100 \mu \mathrm{l}$ of water. DNA was quantified spectrophotometrically, and $200 \mathrm{ng}$ were used as a template for each PCR amplification.

Table I Clinico-pathological features of the series under study as related to $M+$ and $M-$ tumours

\begin{tabular}{|c|c|c|c|c|}
\hline & $\begin{array}{c}\text { All patients } \\
n=202(100 \%)\end{array}$ & $\begin{array}{c}M- \\
n=72(100 \%)\end{array}$ & $\begin{array}{c}M+ \\
n=130(100 \%)\end{array}$ & Univariate analysis \\
\hline Age (years \pm s.d.) & $66.05 \pm 11.66$ & $69.40 \pm 11.44$ & $64.2 \pm 11.40$ & $P=0.002$ \\
\hline \multicolumn{5}{|l|}{ Sex } \\
\hline $\mathrm{F}$ & 81 (40\%) & $26(36 \%)$ & 55 (42\%) & \multirow[t]{2}{*}{ NS } \\
\hline M & $121(60 \%)$ & $46(64 \%)$ & $75(58 \%)$ & \\
\hline L & 78 (39\%) & 30 (42\%) & $48(37 \%)$ & \multirow{2}{*}{ NS } \\
\hline $\operatorname{Re}$ & $53(26 \%)$ & $19(26 \%)$ & $34(26 \%)$ & \\
\hline \multicolumn{5}{|l|}{ Grading } \\
\hline GI & $14(7 \%)$ & 9 (13\%) & $5(4 \%)$ & \multirow[t]{3}{*}{$P=0.069$} \\
\hline G2 & 145 (72\%) & 47 (65\%) & 98 (75\%) & \\
\hline G3 & 43 (21\%) & 16 (22\%) & 27 (21\%) & \\
\hline
\end{tabular}

$\mathrm{F}=$ female; $\mathrm{L}=$ left side; $\mathrm{M}=$ male; $\mathrm{M}+=$ metastatic tumours; $\mathrm{M}-=$ nonmetastatic tumours; $\mathrm{NS}=$ not significant; $\mathrm{R}=$ right side; $R e=$ rectum; s.d. $=$ standard deviation. 


\section{$K$-Ras and B-Raf mutation (PCR-RFLP)}

Mutations at codon 12 of the K-Ras gene and at codon 599 of the $B$-Raf gene were detected by PCR-RFLP that identifies codon 12 and 599 mutations but not the specifically altered nucleotide. $K$-Ras codon 12 mutations were detected using the BstNI restriction enzymes (New England Biolabs Inc., Beverly, MA, USA). Briefly, $200 \mathrm{ng}$ of DNA were used as template for the first PCR, which consisted of a $50 \mu \mathrm{l}$ volume containing Taq DNA polymerase ( $1 \mathrm{U}$; Finnzyme, Espoo, Finland), deoxynucleotide triphosphates (0.2 mm; Finnzyme, Espoo, Finland), reaction buffer $(5 \mu \mathrm{l}$; Finnzyme, Espoo, Finland), the primers forward $\left(0.2 \mathrm{pmol} \mu \mathrm{l}^{-1}\right.$; Proligo, Boulder, CO, USA): $5^{\prime}$-ACTGAATATAAA CTTGTGGTAGTTGGACCT- $3^{\prime}$ and reverse $\left(0.2 \mathrm{pmol} \mu \mathrm{l}^{-1}\right.$; Proligo, Boulder, CO, USA): $5^{\prime}$-TCAAAAGAATGGTCCTGCACCAG- $3^{\prime}$. The forward primer creates the restriction site for Bst NI, which is lost when $K$-Ras is mutated at codon 12 .

For amplification, a DNA thermocycler (MBS 0.2S, Hybaid, Ashford, UK) was used. Cycling conditions of the first PCR were as follows: initial denaturation $\left(4 \mathrm{~min}\right.$ at $\left.94^{\circ} \mathrm{C}\right)$, followed by 40 cycles of denaturation $\left(30 \mathrm{~s}\right.$ at $\left.94^{\circ} \mathrm{C}\right)$, annealing $\left(15 \mathrm{~s}\right.$ at $53^{\circ} \mathrm{C}$ ), and elongation $\left(30 \mathrm{~s}\right.$ at $\left.72^{\circ} \mathrm{C}\right)$. An elongation of $10 \mathrm{~min}$ at $72^{\circ} \mathrm{C}$ followed the last cycle; at the end, samples were kept at $4^{\circ} \mathrm{C}$. Twenty microlitres of the PCR reaction were then digested with $B s t \mathrm{NI}$ for $4 \mathrm{~h}$ at $60^{\circ} \mathrm{C}$ in a total volume of $50 \mu \mathrm{l}$. When codon 12 is wild-type, the PCR product contains a restriction site for Bst $\mathrm{NI}$, and digestion yields bands of 128 and $29 \mathrm{bp}$. If there is a mutation in either of the first two bases of codon 12, the mutant PCR fragment will not be cut and will remain at its original size of $157 \mathrm{bp}$. Digested products were visualised by electrophoresis on a $3 \%$ agarose gels (containing $0.5 \mu \mathrm{g} \mathrm{ml}^{-1}$ ethidium bromide). Positive (SW480 cell line) and negative controls (Human Placental DNA) for the mutation and controls for carryover DNA contamination were included in every experiment. B-Raf V599E mutations were analysed first by amplification using primers forward $\left(0.2 \mathrm{pmol} \mu \mathrm{l}^{-1}\right.$; Proligo, Boulder, CO, USA): 5'-CTGTTTTCCTTTACTTACTACACCTCA GATA- $3^{\prime}$ and reverse $\left(0.2\right.$ pmol $\mu \mathrm{l}^{-1}$; Proligo, Boulder, CO, USA): $5^{\prime}$-CTCAATTCTTACCATCCACAAAATG-3'. After 40 cycles of amplification (annealing temperature $55^{\circ} \mathrm{C}$ ), amplified DNA was subjected to TspRI (New England Biolabs, Beverly, MA, USA) restriction digestion because this mutation abrogates a restriction site present in the wild-type sequence. After incubation with the enzyme at $65^{\circ} \mathrm{C}$ overnight, the products were analysed on $3 \%$ agarose gels. Special care was taken to directly load the samples at high temperature $\left(70^{\circ} \mathrm{C}\right)$ and in the presence of formamide $(0.2 \%)$ to avoid reannealing of the restricted products (Ts $p$ RI leaves a nine-base $3^{\prime}$ overhang). DNA containing the wild-type (Human Placental DNA) or the mutated T1976 sequence (HT29 cell line) was always included as controls.

\section{P53 mutation}

We used both SSCP and immunohistochemistry.

SSCP By SSCP we identified samples with altered p53 migratory pattern, by gene mutation or polymorphism. Briefly, PCR fragments were generated from $200 \mathrm{ng}$ of genomic DNA in a $50 \mu \mathrm{l} \mathrm{PCR}$ reaction buffer. The primers $\left(0.4 \mathrm{pmol} \mu \mathrm{l}^{-1}\right.$; Proligo, Boulder, CO, USA) and the condition for PCR are described in the Table 1 of Supplementary Appendix available on the BJC website. DNA containing the wild-type p53 (Human Placental DNA) was always included as controls. For SSCP analysis, PCR product was mixed with an equal volume of loading buffer containing $100 \%$ formamide (Sigma, Saint Louis, MO, USA), 0.05\% xylene cyanol (Sigma, Saint Louis, MO, USA), and $0.05 \%$ bromphenol blue (Amersham Bioscience Corporation, Buckinghamshire, UK); heated at $96^{\circ} \mathrm{C}$ for $10 \mathrm{~min}$ and put on ice before being loaded on $37.5 \%$ TBE polyacrylamide gels and electrophoresed for $1 \mathrm{~h}$ at
$100 \mathrm{~V}$ and $4-5 \mathrm{~h}$ at $300 \mathrm{~V}$. The gels were silver stained with DNA Silver Staining Kit (Amersham Bioscience Corporation, Buckinghamshire, UK) according to the manufacturer's recommendations.

Immunohistochemistry To analyse p53 expression, formalinfixed paraffin-embedded tissue sections $(2 \mu \mathrm{m})$ were used, deparaffinised and exposed to an antigen retrieval system $(1 \mathrm{~mm}$ EDTA, pH 8, and $98^{\circ} \mathrm{C}$ for $30 \mathrm{~min}$ ) before being incubated with the specific p53 antibody (1:1000, Ab-2, Calbiochem; Oncogene Research Products, Cambridge, MA, USA). Endogenous peroxidase was blocked with $3 \%$ hydrogen peroxide for $20 \mathrm{~min}$ at room temperature. Primary mouse monoclonal antibody was applied for $1 \mathrm{~h}$ at room temperature. Reactive sites were identified with secondary antibody (HRP rabbit/mouse, ChemMate DAKO Envision, Carpinteria, CA, USA) for $30 \mathrm{~min}$ at room temperature. Immunoperoxidase staining, using diaminobenzidine as chromogen, was carried out (DAB + chromogen X-50, ChemMate, DAKOCytomation, Carpinteria, CA, USA). The slides were counterstained with hematoxylin (Harris Hematoxylin, DiaPath, Microstain Division, Martinengo, BG, Italy). An abnormal SSCP pattern coincidental with p53 nuclear immunoreactivity was taken as indicative of cases with $p 53$ mutation. Indeed, an altered SSCP pattern may be merely related to gene polymorphism and as such being not indicative of an abnormally mutated gene. On the other hand, the mere immunocytochemical detection of p53 gene product may also be due to an increased protein stabilisation uncoupled from mutation (Cripps et al, 1994). Therefore, the less expensive, quick and efficient way to detect p53 mutations is to associate an abnormal SSCP pattern with the nuclear immunocytochemical detection of the gene product.

\section{RASSF1A, E- Cadherin and p16INK4A methylation}

As previously reported (Roncalli et al, 2002), $1 \mu \mathrm{g}$ of genomic DNA in a volume of $50 \mu \mathrm{l}$ was denatured by $\mathrm{NaOH}$ for $10 \mathrm{~min}$ at $37^{\circ} \mathrm{C}$; $30 \mu \mathrm{l}$ of $10 \mathrm{~mm}$ hydroquinone (Sigma, Saint Louis, MO, USA) and $520 \mu$ l of $3 \mathrm{M}$ sodium bisulphite (Sigma, Saint Louis, MO, USA) at $\mathrm{pH} 5$, both freshly prepared, were added and mixed, and samples were incubated at $50^{\circ} \mathrm{C}$ for $16 \mathrm{~h}$. Modified DNA was purified using the Wizard DNA purification resin according to the manufacturer's instruction (Promega, Milano, Italy) and eluted into $50 \mu \mathrm{l}$ of water. Modification was completed by $\mathrm{NaOH}$ treatment (final concentration $0.3 \mathrm{M}$ ) for $5 \mathrm{~min}$ at room temperature, followed by ethanol precipitation. DNA was resuspended in water and used immediately or stored at $-20^{\circ} \mathrm{C}$. Polymerase chain reaction was performed separately with methylation-specific primers (0.12 pmol $\mu \mathrm{l}^{-1}$; Proligo, Boulder, CO, USA) and unmethylation primers $\left(0.12 \mathrm{pmol}^{-1} \mathrm{l}^{-1}\right.$; Proligo, Boulder, CO, USA) for each gene (Supplementary Appendix, Table 1). Unmethylated (Human Placental DNA) and methylated DNA (LoVo, COLO320 and HepG2 cell lines for RASSF1A, E-Cadherin and p16INK4A, respectively) were used as MSP controls. Polymerase chain reaction products were analysed on $2 \%$ agarose gels, stained with ethidium bromide $\left(0.5 \mu \mathrm{g} \mathrm{ml}^{-1}\right)$, and visualised under UV illumination. A sample was classified as methylated whenever a band, corresponding to the molecular weight of the methylated PCR product, had a thickness and staining intensity equal or greater than that of the unmethylated PCR product. Figure 1 of Supplementary Appendix available on the BJC website illustrates an example of methylated and unmethylated PCR products.

\section{Statistical analyses}

Data were described as number and percentage or means and s.d., whether appropriate. Differences in frequencies of variables were tested using the $\chi^{2}$ test (Pearson or Fisher, if appropriate), and differences in mean levels of variables were tested using the $t$-test. 
A $P$-value of 0.05 was considered statistically significant. All variables found to have a $P$-value $\leqslant 0.1$ in the univariate evaluation were considered to be candidates for a subsequent stepwise multivariate logistic regression analysis. Data analysis was performed using STATA9.

\section{RESULTS}

\section{Genetic changes}

The mutational status of $K$-Ras, $B$-Raf and $p 53$ in 202 cases of CRC is shown in Table $2 \mathrm{a}$.

$\mathrm{K}$-Ras Codon $12 \mathrm{~K}$-Ras mutations were found in 54 cases $(27 \%)$. By univariate analysis, $K$-Ras mutations were significantly associated with $\mathrm{M}+$ tumours $(P=0.016)$ and more frequent detectable in the right side $(P=0.088)$. Multivariate analysis confirmed the association between $K$-Ras mutations and $\mathrm{M}+$ tumours (OR 2.37, 95\% CI, 1.15-4.88, $P=0.019$ ).

B-Raf Seven cases (3\%) showed B-Raf mutation but none of these had a coincidental mutation in the $K$-Ras gene nor a statistical association with the other clinico-pathological variables.

p53 An altered SSCP pattern was identified in 91 (45\%) out of 202 samples, whereas p53 nuclear immunoreactivity was detected in $115(57 \%)$ out of 202 cases. A coincidental abnormal SSCP migratory pattern and p53 nuclear immunoreactivity was documented in $65(32 \%)$ out of 202 cases.

No association was found in cases showing both genetic and phenotypic p53 abnormalities with the clinico-pathological parameters under study.

\section{Epigenetic changes}

All cases showing PCR products for methylated DNA sequences also exhibited unmethylated DNA sequences, which was related to tumour heterogeneity or to the occurrence of intermingled nonneoplastic cells. The epigenetic profile of RASSF1A, E-Cadherin and p16INK4A in CRC is shown in Table $2 \mathrm{~b}$.
RASSF1A Out of 202 tumours, RASSF1A was methylated in 40 $(20 \%)$ tumours, the majority occurring in $\mathrm{M}+$ tumours $(P=0.021)$. No other association was found between RASSF1A methylation and the clinico-pathological parameters under study.

E-Cadherin Out of 202 cases, E-Cadherin methylation was detected in $88(44 \%)$ cases. E-Cadherin methylation was more frequently detectable in the right colon $(P=0.011)$ and in older patients $(P=0.002)$. E-Cadherin methylation was also associated with $R A S S F 1 A$ methylation $(P=0.047)$. All these variables retained a statistical significance in multivariate analysis (right side: OR $0.59,95 \% \mathrm{CI}, 0.40-0.87, P=0.007$; older age: OR $1.039,95 \% \mathrm{CI}$, $1.01-1.07, P=0.004$; RASSF1A methylation: OR $2.11,95 \% \mathrm{CI}$, $1.01-4.41, P=0.047)$.

p16INK4A Out of 202 cases, p16INK4A promoter methylation was found in $67(33 \%)$ cases. p16INK4A methylation was significantly associated with $\mathrm{M}+$ tumours $(P<0.001) . p 16 I N K 4 A$ methylation was associated with $B$-Raf mutations $(P<0.001)$, RASSF1A $(P=0.004)$ and E-Cadherin $(P=0.040)$ methylation. p16INK4A methylation was more frequently detectable in $p 53$ mutated cases $(P=0.075)$. Multivariate analysis showed that gene methylation was statistically associated with $\mathrm{M}+$ tumours (OR 3.48, 95\% CI, 1.66-7.26, $P=0.001)$ and with RASSF1A methylation (OR 2.29, 95\% CI, 1.07-4.89, $P=0.032$ ).

\section{Coincidental genetic and epigenetic changes}

Out of 202 CRCs, thirty-four (17\%) were free from molecular abnormalities and with no association with $\mathrm{M}+v s \mathrm{M}-$ tumours. Regardless the type of molecular abnormalities, 68 cases $(34 \%)$ showed one molecular alteration, 57 cases $(28 \%)$ two molecular alterations and 43 cases $(21 \%) \geqslant 3$ molecular alterations. No statistical association was seen between $\mathrm{M}+$ and $\mathrm{M}-\mathrm{CRCs}$ showing one or two gene alterations. Conversely, the frequency of CRCs in the group showing three or more alterations was higher in $\mathrm{M}+$ than in $\mathrm{M}-$ tumours $(34 / 130=26 \%$ vs $9 / 72=12 \%$; $P=0.023)$. In the latter ( $\geqslant 3$ abnormalities) group, the most frequent combination of genes was one genetic and two epigenetic alterations, particularly $K$-Ras mutations $(18 / 34=53 \%)$, with gene methylation equally affecting the three genes under study (RASSF1A, E-Cadherin and p16INK4A). Coincidental methylation

Table 2a Genetic alterations: mutation frequencies for K-Ras, B-Raf and p53

\begin{tabular}{|c|c|c|c|c|c|c|c|}
\hline & $\begin{array}{c}\text { All cases } \\
\text { No. }\end{array}$ & $\begin{array}{c}\text { K-Ras } \\
\text { No. (\%) }\end{array}$ & & $\begin{array}{c}\text { B-Raf } \\
\text { No. (\%) }\end{array}$ & & $\begin{array}{c}\text { p53 } \\
\text { No. (\%) }\end{array}$ & \\
\hline All patients & 202 & $54(27 \%)$ & & $7(3 \%)$ & & 65 (32\%) & \\
\hline Age (years \pm s.d.) & $66.05 \pm 11.66$ & $67.16 \pm 11.56$ & NS & $64.42 \pm 13.50$ & NS & $65.23 \pm 12.17$ & NS \\
\hline \multicolumn{8}{|l|}{$\operatorname{Sex}$} \\
\hline$F$ & 81 & $24(30 \%)$ & NS & $2(2 \%)$ & NS & $22(27 \%)$ & NS \\
\hline$M$ & 121 & $30(25 \%)$ & & $5(4 \%)$ & & $43(35 \%)$ & \\
\hline \multicolumn{8}{|l|}{ Tumour } \\
\hline M- & 72 & $12(17 \%)$ & $P=0.016$ & I (1\%) & NS & $26(36 \%)$ & NS \\
\hline$M+$ & 130 & $42(32 \%)$ & & $6(5 \%)$ & & $39(23 \%)$ & \\
\hline \multicolumn{8}{|l|}{ Location } \\
\hline $\mathrm{R}$ & 71 & 25 (35\%) & & $5(7 \%)$ & & $23(32 \%)$ & \\
\hline L & 78 & $15(19 \%)$ & $P=0.088$ & I (1\%) & NS & $23(29 \%)$ & NS \\
\hline $\operatorname{Re}$ & 53 & $14(26 \%)$ & & I (2\%) & & $19(36 \%)$ & \\
\hline \multicolumn{8}{|l|}{ Grading } \\
\hline $\mathrm{Gl}^{\circ}$ & 14 & $5(36 \%)$ & & - & & $4(29 \%)$ & \\
\hline G2 & 145 & $38(26 \%)$ & NS & $4(3 \%)$ & NS & $48(33 \%)$ & NS \\
\hline G3 & 43 & II (26\%) & & $3(7 \%)$ & & $13(30 \%)$ & \\
\hline
\end{tabular}

$\mathrm{F}=$ female; $\mathrm{L}=$ left side; $M=$ male; $M+=$ metastatic tumours; $M-=$ nonmetastatic tumours; $N S=$ not significant; $R=$ right side; $R e=$ rectum; s.d. = standard deviation. 
Table 2b Epigenetic alterations: promoter methylation frequencies for RASSFIA, E-Cadherin and p I 6INK4A

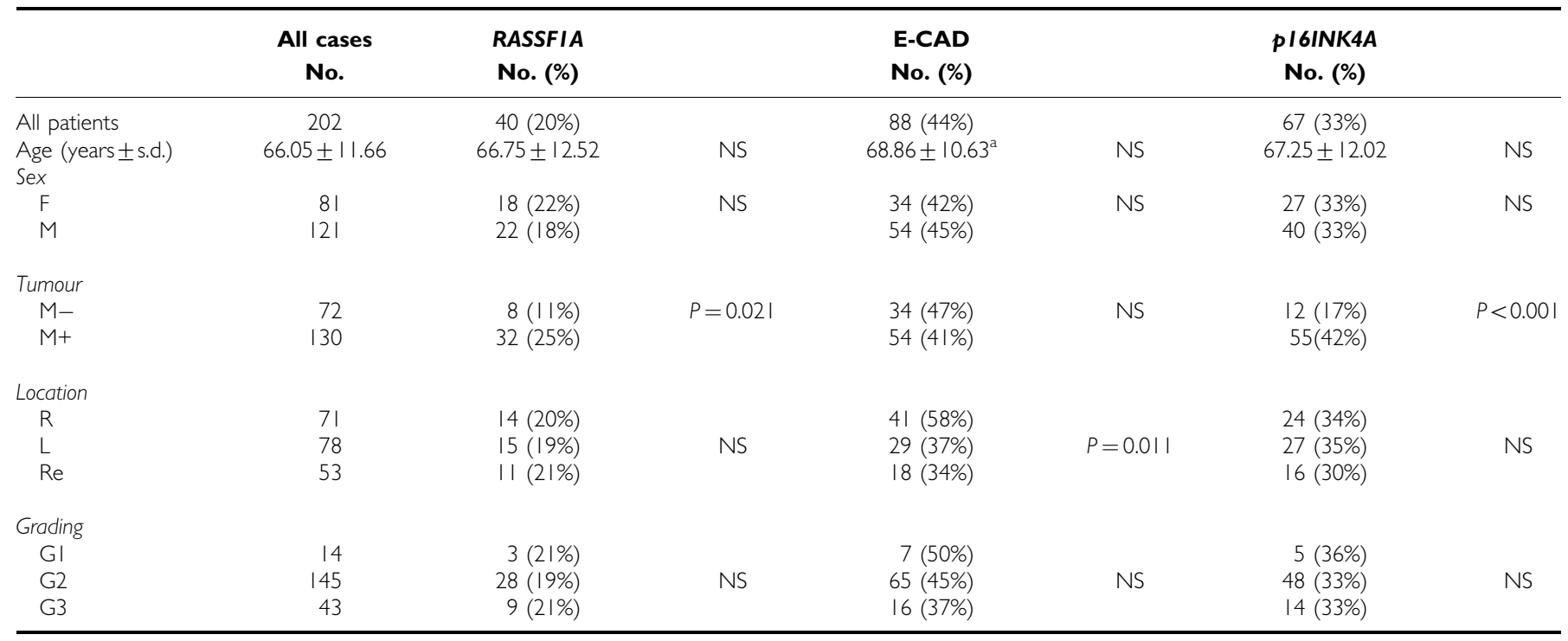

$\mathrm{F}=$ female; $\mathrm{L}=$ left side; $M=$ male; $M+=$ metastatic tumours; $M-=$ nonmetastatic tumours; $N S=$ not significant; $R=$ right side; Re = rectum; s.d. $=$ standard deviation. a Methylated vs nonmethylated $=68.86 \pm 10.63$ vs $63.89 \pm 11.99(P=0.002)$.

of these genes was also documented in 12 cases, 11 of whose were $\mathrm{M}+\mathrm{CRCs}(P=0.042)$.

\section{Multivariate analysis of variables associated with $\mathrm{M}+$ tumours}

Among the variables associated with $\mathrm{M}+$ cancers in univariate analysis (K-Ras mutation, p16INK4A methylation, RASSF1A methylation, younger age and grading), multivariate analysis showed that only $K$-Ras mutations (OR 2.98, 95\% CI, 1.37-6.46, $P=0.006$ ), p16INK4A methylation (OR 4.58, 95\% CI, 2.14-9.76, $P<0.001$ ) and younger age (OR 0.95, 95\% CI, $0.92-0.98, P<0.001$ ) retained a statistically significant value.

\section{DISCUSSION}

Aim of this study was to characterise genetic and epigenetic molecular alterations occurring in primary advanced $\mathrm{M}+$ and $\mathrm{M}-$ CRCs.

The model of CRC relies upon the sequential accumulation of genetic and epigenetic changes but, in our study, $17 \%$ of cases had no abnormalities in the investigated genes ( $K$-Ras, $B-R a f, p 53$, RASSF1A, E-Cadherin, p16INK4A). These data are in agreement with previous studies examining different sets of genes. Smith et al (2002) investigated K-Ras, p53 and APC in 106 cases and 10\% CRC were reported free of molecular abnormalities. Lee et al (2004) examined promoter methylation of 12 different genes in 149 CRCs and found that $9 \%$ were unmethylated. Chiang et al (2004) also demonstrated that the three key mutations (APC, $K$-Ras and $p 53$ ) are rarely coincidental in 122 sporadic CRCs. All these findings suggest that alterations in the genes mostly involved in colorectal carcinogenesis are not always requested for tumour progression.

We found $27 \% \mathrm{~K}$-Ras mutations in the whole series and a statistical association with $\mathrm{M}+$ tumours (univariate analysis $P=0.016$; multivariate analysis $P=0.019$ ), suggesting $K-R a s$ activation as an important determinant of extracolic tumour spread. Gonzalez-Aguilera et al (2004) found increased $K$-Ras mutations in tumours with advanced Duke's stage (A 22\%, B 27\%, C $38 \%$ and D 33\%), particularly when grouping $M+(46 \%)$ vs $M-$ tumours (26\%). Aberrant activation of $K$-Ras has been implicated in facilitating all aspects of a malignant phenotype, including proliferation, invasion and metastases by Ras effectors such as PIK3, Raf/MEK/ERK cascade and Rho GTPases. Recently, some authors proposed that epithelial cells with activated Ras signalling require the cooperation of other signalling pathway to became metastogenic (Grunert et al, 2003) and the oncogenic Ras is thought to cooperates with several other proto-oncogenes such as p53 and p16INK4A (Serrano et al, 1996; Aguirre et al, 2003). This cooperation between Ras and other genes is likely to occur in CRC progression because, in our study, only $6 \%$ of tumours showed the exclusive presence of $K$-Ras mutation. E-Cadherin promoter methylation was prevalent in the right colon (univariate analysis $P=0.011$; multivariate analysis $P=0.007$ ), so that coincidental $K$-Ras mutations and E-Cadherin methylation frequently occurred in proximal $(27 \%)$ rather than left colon $(5 \%)$ and rectum $(8 \%)$ $(P<0.001)$. Whether E-Cadherin methylation and $K$-Ras mutation cooperate in right side colonic carcinogenesis and progression have to be confirmed in larger series. B-Raf was rarely found mutated in our cases and never in conjunction with $K$-Ras. As previously noted (Rajagopalan et al, 2002; Yuen et al, 2002), K-Ras and $B$-Raf mutations appear to be mutually exclusive, confirming previous suggestions that they have similar biological targets in the RAS-RAF-MEK-ERK-MAP kinase signalling pathway (Yuen et al, 2002). A small proportion of cases $(10 / 202=5 \%)$ showed both $K$-Ras mutations and RASSF1A methylation; interestingly all these cases were $\mathrm{M}+(P=0.016)$. Whether alterations in both these genes may be able to confer a more aggressive phenotype remains to be established in larger series.

In our study, p53 abnormalities were not prevalent in $\mathrm{M}+$ tumours suggesting a limited role of $p 53$ in CRC metastatisation. Different results were reported by Goh et al (1999) that used only SSCP to detect $p 53$ mutations.

Among tumour suppressor genes showing DNA methylation, p16INK4A seems to play a major role in the metastogenic phenotype of primary CRCs. Methylation was seen in $33 \%$ of the whole series and it was, like K-Ras mutation, significantly associated with a $\mathrm{M}+$ phenotype (univariate analysis $P=0.011$; multivariate analysis $P=0.001$ ). A strong correlation between staging and p16INK4A methylation was found also by $\mathrm{Yi}$ et al (2001); loss of p16INK4A expression has been previously associated with lymph-node metastases (Kim et al, 2005a) and 
more advanced stage (Jeong et al, 2005). Altogether, these results suggest that $p 16 I N K 4 A$ methylation might link to a more malignant phenotype in CRC; interestingly Liang et al (1999) recently reported an association between p16INK4A methylation and shorter survival of CRC. Coincidental alterations of $K$-Ras and p16INK4A were mainly found in $\mathrm{M}+$ tumours $(2 / 67$ $\mathrm{M}$ - tumours vs $17 / 139 \mathrm{M}+$ tumours; $P=0.034$ ), suggesting that abnormalities in these pathways could cooperate for a more aggressive phenotype, as previously supported by Serrano et al (1997).

Another focus of this study was to examine the interactions between genetic and epigenetic alterations in the induction of a metastogenic phenotype. Regardless the type of molecular abnormalities, tumours with three or more but not those with less than three, were significantly more prevalent in the group of $\mathrm{M}+$ tumours $(P=0.023)$. This means that the genes under study can confer a more aggressive phenotype when molecular changes deregulate at least three of them. This hypothesis is in keeping with a stepwise model of progression of CRC. Given that a fraction of M- CRCs (13\%) already harbours three or more molecular changes, we are currently analysing this cohort to ascertain whether these cases will develop metachronous liver metastasis at an increase rate as compared to $\mathrm{M}-\mathrm{CRCs}$ with $<3$ molecular changes. The group of $\mathrm{M}+$ tumours showing three or more abnormal genes was characterised by a single genetic mutation (usually $K$-Ras; $53 \%$ ) and by two epigenetic alterations (equally affecting p16INK4A, RASSF1A and E-Cadherin). Notably, Toyota et al (2000) found $K$-Ras mutations significantly prevalent in CRCs with the so called methylator phenotype (CIMP) compared with CIMP negative cases. A stepwise increase in the number of methylated genes was observed with lesion progression through

\section{REFERENCES}

Aguirre AJ, Bardeesy N, Sinha M, Lopez L, Tuveson DA, Horner J, Redston MS, DePinho RA (2003) Activated Kras and Ink4a/Arf deficiency cooperate to produce metastatic pancreatic ductal adenocarcinoma. Genes Dev 17: 3112 - 3126

Bazan V, Migliavacca M, Zanna I, Tubiolo C, Grassi N, Latteri MA, La Farina M, Albanese I, Dardanoni G, Salerno S, Tomasino RM, Labianca R, Gebbia N, Russo A (2002) Specific codon 13 K-ras mutations are predictive of clinical outcome in colorectal cancer patients, whereas codon $12 \mathrm{~K}$-ras mutations are associated with mucinous histotype. Ann Oncol 13: $1438-1446$

Chiang JM, Wu Chou YH, Ma SC, Chen JR (2004) Influence of age on adenomatous polyposis coli and p53 mutation frequency in sporadic colorectal cancer-rarity of co-occurrence of mutations in APC, K-ras, and p53 genes. Virchows Arch 445: 465-471

Cripps KJ, Purdie CA, Carder PJ, White S, Komine K, Bird CC, Wyllie AH (1994) A study of stabilisation of p53 protein versus point mutation in colorectal cancer. Oncogene 9: 2739-2743

Dammann R, Schagdarsurengin U, Strunnikova M, Rastetter M, Seidel C, Liu L, Tommasi S, Pfeifer GP (2003) Epigenetic inactivation of the Rasassociation domain family 1 (RASSF1A) gene and its function in human carcinogenesis. Histol Histopathol 18: 665-677

Darwanto A, Kitazawa R, Maeda S, Kitazawa S (2003) MeCP2 and promoter methylation cooperatively regulate $\mathrm{E}$-cadherin gene expression in colorectal carcinoma. Cancer Sci 94: $442-447$

Davies H, Bignell GR, Cox C, Stephens P, Edkins S, Clegg S, Teague J, Woffendin H, Garnett MJ, Bottomley W, Davis N, Dicks E, Ewing R, Floyd Y, Gray K, Hall S, Hawes R, Hughes J, Kosmidou V, Menzies A, Mould C, Parker A, Stevens C, Watt S, Hooper S, Wilson R, Jayatilake H, Gusterson BA, Cooper C, Shipley J, Hargrave D, Pritchard-Jones K, Maitland N, Chenevix-Trench G, Riggins GJ, Bigner DD, Palmieri G, Cossu A, Flanagan A, Nicholson A, Ho JW, Leung SY, Yuen ST, Weber BL, Seigler HF, Darrow TL, Paterson H, Marais R, Marshall CJ, Wooster R, Stratton MR, Futreal PA (2002) Mutations of the BRAF gene in human cancer. Nature 417: 949-954 de la Chapelle A (2004) Genetic predisposition to colorectal cancer. Nat Rev Cancer 4: 769-780 the stages of multistep colorectal carcinogenesis by Lee et al (2004). Our study showed that coincidental methylation of the three genes (RASSF1A, E-Cadherin and p16INK4A) was restricted to $\mathrm{M}+$ tumours $(P=0.042)$. It is unclear why advanced and $\mathrm{M}+$ CRCs showed a high degree of methylation: perhaps advanced tumours inherited a major biological aggressiveness or were simply more likely to become methylated. Notably, patients showing three methylated genes were also of older age (73.83 vs 65.60 years; $P=0.017$ ), in keeping with the suggestion put forwards by Toyota and Issa (1999) that age-related methylation might contribute to the sharp increase in cancer risk after the age of 60 years.

Interestingly, in the present study, younger age was statistically associated to $\mathrm{M}+$ tumours. This is likely due to internal selection for surgical treatment, being the older age a limiting factor for radical surgical resection (Leporrier et al, 2006).

In conclusion, analysis of a panel of genes provided to detect some genetic and epigenetic molecular differences between $\mathrm{M}+$ and $\mathrm{M}$ - primary CRCs. A set of genetic and epigenetic molecular abnormalities is a feature of primary $\mathrm{M}+\mathrm{CRCs}$ likely conferring the ability for tumour extracolic spread and determining markers for aggressive behaviour and potential therapeutic targets.

\section{ACKNOWLEDGEMENTS}

This paper was supported by MURST (COFIN 2003).

Supplementary information accompanies the paper on British Journal of Cancer website (http://www.nature.com/bjc)
Fearon ER, Vogelstein B (1990) A genetic model for colorectal tumorigenesis. Cell 61: 759-767

Garinis GA, Menounos PG, Spanakis NE, Papadopoulos K, Karavitis G, Parassi I, Christeli E, Patrinos GP, Manolis EN, Peros G (2002) Hypermethylation-associated transcriptional silencing of E-cadherin in primary sporadic colorectal carcinomas. J Pathol 198: $442-449$

Giehl K (2005) Oncogenic Ras in tumour progression and metastasis. Biol Chem 386: $193-205$

Goh HS, Elnatan J, Low CH, Smith DR (1999) p53 point mutation and survival in colorectal cancer patients: effect of disease dissemination and tumour location. Int J Oncol 15: 491-498

Gonzalez-Aguilera JJ, Oliart S, Azcoita MM, Fernandez-Peralta AM (2004) Simultaneous mutations in K-ras and TP53 are indicative of poor prognosis in sporadic colorectal cancer. Am J Clin Oncol 27: 39-45

Grunert S, Jechlinger M, Beug H (2003) Diverse cellular and molecular mechanisms contribute to epithelial plasticity and metastasis. Nat Rev Mol Cell Biol 4: 657-665

Jeong J, Park YN, Park JS, Yoon DS, Chi HS, Kim BR (2005) Clinical significance of p16 protein expression loss and aberrant p53 protein expression in pancreatic cancer. Yonsei Med J 46: 519-525

Kamb A, Shattuck-Eidens D, Eeles R, Liu Q, Gruis NA, Ding W, Hussey C, Tran T, Miki Y, Weaver-Feldhaus J (1994) Analysis of the p16 gene (CDKN2) as a candidate for the chromosome $9 \mathrm{p}$ melanoma susceptibility locus. Nat Genet 8: $23-26$

Kim BN, Yamamoto H, Ikeda K, Damdinsuren B, Sugita Y, Ngan CY, Fujie Y, Ogawa $M$, Hata $T$, Ikeda $M$, Ohue $M$, Sekimoto $M$, Monden $T$, Matsuura N, Monden M (2005a) Methylation and expression of p16INK4 tumor suppressor gene in primary colorectal cancer tissues. Int J Oncol 26: $1217-1226$

Kim HC, Roh SA, Ga IH, Kim JS, Yu CS, Kim JC (2005b) CpG island methylation as an early event during adenoma progression in carcinogenesis of sporadic colorectal cancer. J Gastroenterol Hepatol 20: $1920-1926$

Kolch W (2000) Meaningful relationships: the regulation of the Ras/Raf/ MEK/ERK pathway by protein interactions. Biochem J 351: 289-305 
Lee S, Hwang KS, Lee HJ, Kim JS, Kang GH (2004) Aberrant CpG island hypermethylation of multiple genes in colorectal neoplasia. Lab Invest 84: $884-893$

Leporrier J, Maurel J, Chiche L, Bara S, Segol P, Launoy G (2006) A population-based study of the incidence, management and prognosis of hepatic metastases from colorectal cancer. Br J Surg 93: 465-474

Liang JT, Chang KJ, Chen JC, Lee CC, Cheng YM, Hsu HC, Wu MS, Wang SM, Lin JT, Cheng AL (1999) Hypermethylation of the p16 gene in sporadic T3N0M0 stage colorectal cancers: association with DNA replication error and shorter survival. Oncology 57: 149-156

Pizzi S, Azzoni C, Bottarelli L, Campanini N, D’Adda T, Pasquali C, Rossi G, Rindi G, Bordi C (2005) RASSF1A promoter methylation and 3p21.3 loss of heterozygosity are features of foregut, but not midgut and hindgut, malignant endocrine tumours. J Pathol 206: 409-416

Pollock CB, Shirasawa S, Sasazuki T, Kolch W, Dhillon AS (2005) Oncogenic $\mathrm{K}$-RAS is required to maintain changes in cytoskeletal organization, adhesion, and motility in colon cancer cells. Cancer Res 65: 1244-1250

Rajagopalan H, Bardelli A, Lengauer C, Kinzler KW, Vogelstein B, Velculescu VE (2002) Tumorigenesis: RAF/RAS oncogenes and mismatch-repair status. Nature 418: 934

Remvikos Y, Laurent-Puig P, Salmon RJ, Frelat G, Dutrillaux B, Thomas G (1990) Simultaneous monitoring of P53 protein and DNA content of colorectal adenocarcinomas by flow cytometry. Int J Cancer 45: 450 - 456

Roncalli M, Bianchi P, Bruni B, Laghi L, Destro A, Di Gioia S, Gennari L, Tommasini M, Malesci A, Coggi G (2002) Methylation framework of cell cycle gene inhibitors in cirrhosis and associated hepatocellular carcinoma. Hepatology 36: 427-432

Serrano M, Lee H, Chin L, Cordon-Cardo C, Beach D, DePinho RA (1996) Role of the INK4a locus in tumor suppression and cell mortality. Cell 85: 27-37
Serrano M, Lin AW, McCurrach ME, Beach D, Lowe SW (1997) Oncogenic ras provokes premature cell senescence associated with accumulation of p53 and p16 ${ }^{\mathrm{INK} 4 \mathrm{a}}$. Cell 88: $593-602$

Smith G, Carey FA, Beattie J, Wilkie MJ, Lightfoot TJ, Coxhead J, Garner RC, Steele RJ, Wolf CR (2002) Mutations in APC, Kirsten-ras, and p53 alternative genetic pathways to colorectal cancer. Proc Natl Acad Sci USA 99: $9433-9438$

Takeichi M (1995) Morphogenetic roles of classic cadherins. Curr Opin Cell Biol 7: 619-627

Toyota M, Issa JP (1999) CpG island methylator phenotype in aging and cancer. Semin Cancer Biol 9: 349-357

Toyota M, Ohe-Toyota M, Ahuja N, Issa JP (2000) Distinct genetic profiles in colorectal tumors with or without the $\mathrm{CpG}$ island methylator phenotype. Proc Natl Acad Sci USA 97: 710-715

Wheeler JM, Kim HC, Efstathiou JA, Ilyas M, Mortensen NJ, Bodmer WF (2001) Hypermethylation of the promoter region of the E-cadherin gene $(\mathrm{CDH} 1)$ in sporadic and ulcerative colitis associated colorectal cancer. Gut 48: $367-371$

Yi J, Wang ZW, Cang H, Chen YY, Zhao R, Yu BM, Tang XM (2001) p16 gene methylation in colorectal cancers associated with Duke's staging. World J Gastroenterol 7: 722-725

Yuen ST, Davies H, Chan TL, Ho JW, Bignell GR, Cox C, Stephens P, Edkins S, Tsui WW, Chan AS, Futreal PA, Stratton MR, Wooster R, Leung SY (2002) Similarity of the phenotypic patterns associated with BRAF and KRAS mutations in colorectal neoplasia. Cancer Res 62: $6451-6455$

Zhang JS, Caplin S, Bosman FT, Benhattar J (1997) Genetic diversity at the p53 locus between primary human colorectal adenocarcinomas and their lymph-node metastases. Int J Cancer 70: 674-678 